\title{
PEMBUATAN BIOETANOL DARI BIJI SALAK (Salacca edulis) MELALUI FERMENTASI
}

\author{
Production of Bioethanol from Salak Seed (Salacca edulis) through Fermentation
}

\author{
*Yuni Anggraeni, Supriadi, dan Kasmudin Mustapa \\ Pendidikan Kimia/FKIP - Universitas Tadulako, Palu - Indonesia 94118 \\ Received 21 June 2017, Revised 21 July 2017, Accepted 23 August 2017
}

\begin{abstract}
Salak seed is a waste of salak fruit that contains a high carbohydrates, therefore it can be used as an alternative raw material for production of bioethanol. The study aims to determine the optimum time of fermentation to produce the highest content of bioethanol and to determine the weight ratio of the yeast and the substrate that produce the highest content of bioethanol. Variations of yeast mass used was 2, 4, and 6 grams and fermentation time was 24, 48, $72,96,120$, and 144 hours. The analysis showed that the highest content of bioethanol produced was 6 grams of the yeast mass, the fermentation time was 48 hours and the weight ratio of yeast to the substrate was 6: 10 that obtained $11.2 \%$.
\end{abstract}

Keywords: Bioethanol, salak seed, fermentation, yeast, hydrolysis

\section{Pendahuluan}

Menipisnya cadangan bahan bakar fosil dan meningkatnya populasi manusia sangat kontradiktif dengan kebutuhan energi bagi keberlangsungan hidup manusia beserta aktivitas ekonomi dan sosialnya. Sejak enam tahun terakhir, Indonesia mengalami penurunan produksi minyak bumi nasional akibat menurunnya cadangan minyak pada sumur-sumur produksi secara ilmiah, hal ini berakibat terjadinya kelangkaan BBM. Melihat kondisi tersebut, pemerintah telah mengeluarkan peraturan Presiden Republik Indonesia Nomor 5 Tahun 2006 tentang Kebijakan Energi Nasional untuk mengembangkan sumber energi alternatif sebagai pengganti BBM (Setyaningsih, 2012).

Bioetanol adalah suatu bahan bakar alternatif yang diolah dari tumbuhan (biomassa) dengan cara fermentasi, dimana memiliki keunggulan mampu menurunkan emisi $\mathrm{CO}_{2}$ hingga $18 \%$. Bioetanol di Indonesia, sangat potensial untuk diolah dan dikembangkan karena bahan bakunya merupakan jenis tanaman yang banyak tumbuh di negara ini dan sangat dikenal masyarakat. Tumbuhan yang potensial untuk menghasilkan bioetanol adalah tanaman yang memiliki kadar karbohidrat tinggi (Fauzi, 2011).

Biji salak merupakan salah satu limbah dari buah salak yang memiliki kandungan kimia utama berupa karbohidrat. Tanaman salak merupakan buah khas dari Indonesia yang dapat ditemukan hampir di setiap daerah. Selain produksi salak yang cukup tinggi biji salak mengandung karbohidrat yang berpotensi sebagai bahan baku dalam pembuatan bioetanol karena memiliki kandungan karbohidrat sebanyak $38,9 \%$. Hal ini memungkinkan untuk dapat digunakan sebagai bahan baku dalam pembuatan bioetanol (Nico, 2012).

\section{${ }^{*}$ Correspondence}

Yuni Anggraeni

Program Studi Pendidikan Kimia, Fakultas Keguruan dan IImu Pendidikan, Universitas Tadulako

e-mail: anggraeniyuni1@gmail.com

Published by Universitas Tadulako 2017
Pati dapat diubah menjadi glukosa (gula) melalui proses hidrolisis dengan bantuan asam, misalnya asam klorida $(\mathrm{HCl})$, sedangkan untuk mengubah gula menjadi etanol diperlukan ragi Saccharomyces cereviceae (Gusmarwani, dkk., 2010). Proses hidrolisis pati yaitu pengubahan molekul pati menjadi monomernya seperti glukosa. Hidrolisis pati dapat dilakukan dengan bantuan asam atau enzim pada suhu, $\mathrm{pH}$, dan waktu reaksi tertentu. Hidrolisis pati dengan cara kimiawi dilakukan dengan menggunakan asam-asam organik sebagai katalis. Asam yang sering digunakan pada proses hidrolisis ini adalah $\mathrm{H}_{2} \mathrm{SO}_{4}$, $\mathrm{HCl}$, dan $\mathrm{HNO}_{3}$. (Mastuti \& Setyawardhani, 2010)

Tahap pertama dalam fermentasi glukosa selalu terbentuk asam piruvat melalui jalur embden meyerhof parnas (EMP) atau glikolisis. Piruvat tersebut diubah menjadi alkohol melalui dua tahap yaitu pertama, piruvat didekarboksilasi menjadi asetaldehid oleh piruvat dekarboksilase dengan melibatkan tiamin pirofosfat dan tahap kedua asetaldehid oleh alkohol dehidrogenase direduksi dengan $\mathrm{NADH}_{2}$ menjadi alkohol (Idral, dkk., 2012)

Penelitian tentang bioetanol telah dilakukan sebelumnya oleh (Jhonprimen, dkk., 2011) dimana pembuatan bioetanol dilakukan melalui fermentasi dengan menambahkan ragi roti (saccharomyces cerevisiae). Fermentasi dilakukan dengan variasi waktu yaitu 3 hari dan 7 hari dengan penambahan variasi berat ragi 5, 7, dan $10 \mathrm{~g}$. Etanol yang dihasilkan dari proses fermentasi dipisahkan melalui evaporasi. Hasil penelitian ini, diperoleh kadar etanol terbesar, yaitu $24,01 \%$ pada fermentasi optimum 3 hari, dengan rasio berat bahan baku dengan volume katalis sebesar $250 \mathrm{~mL}: 3 \%$.

Fermentasi adalah proses penguraian karbohidrat menjadi etanol dan $\mathrm{CO}_{2}$ yang dihasilkan oleh aktivitas suatu jenis mikroba yang disebut khamir dalam keadaan anaerob (Osvaldo, dkk., 2012). Variasi waktu pada tahap hidrolisis atau fermentasi dapat dilakukan untuk mendapatkan hasil yang optimum, Oleh karena itu, pada fermentasi perlu diketahui waktu terbaik fermentasinya agar etanol yang dihasilkan dapat optimal (Yusak, 2003). 
Tulisan ini dimaksudkan untuk mendeskripsikan lama waktu fermentasi optimum dan perbandingan berat ragi dengan substrat yang dapat menghasilkan kadar bioetanol tertinggi.

\section{Metode}

Peralatan yang digunakan dalam penelitian ini adalah blender, oven, gelas kimia, labu ukur, gelas ukur, erlenmeyer, pipet tetes, corong, penangas listrik, $\mathrm{pH}$ meter, batang pengaduk, magnet stirer, neraca analitik, ayakan 60 mesh, aluminium foil, alkoholmeter, kertas saring, seperangkat alat evaporator.

Bahan-bahan yang digunakan yaitu biji salak, $\mathrm{HCl}$ (Merck), urea $\left(\left(\mathrm{NH}_{2}\right)_{2} \mathrm{CO}\right)$ (Merck), ammonium sulfat $\left(\left(\mathrm{NH}_{4}\right)_{2} \mathrm{SO}_{4}\right)$ (Merck), $\mathrm{NaOH}$ (Merck), ragi roti (saccharomyces cereviseae), dan aquades $\left(\mathrm{H}_{2} \mathrm{O}\right)$.

\section{Prosedur Kerja}

\section{Tahap penyajian sampel}

Sampel biji salak yang sudah dibersihkan ditimbang sebanyak $2,5 \mathrm{~kg}$, selanjutnya dimasukkan ke dalam oven pada suhu $100{ }^{\circ} \mathrm{C}$ selama 24 jam. Biji salak yang sudah kering dihaluskan dengan menggunakan blender hingga menjadi tepung, selanjutnya biji salak yang telah menjadi tepung diayak dengan menggunakan ayakan 60 mesh.

\section{Tahap hidrolisis}

10 gram tepung biji salak ditimbang dan dimasukkan ke dalam masing-masing 18 erlenmeyer, selanjutnya ditambahkan dengan larutan $\mathrm{HCl} 21 \%$ masing-masing sebanyak $100 \mathrm{~mL}$ dan dipanaskan pada suhu $100^{\circ} \mathrm{C}$ selama 75 menit. Kemudian larutan tersebut disaring dengan menggunakan kertas saring dan didinginkan.

\section{Tahap fermentasi}

Proses fermentasi dilakukan pada filtrat hasil hidrolisis kemudian ditambahkan larutan $\mathrm{NaOH} 6 \mathrm{M}$ hingga $\mathrm{pH}$-nya menjadi 5 . Kemudian masing-masing larutan ditambahkan 2 gram urea dan 2 gram ammonium sulfat dan dipasteurisasi pada suhu $80^{\circ} \mathrm{C}$ selama 15 menit lalu didinginkan, selanjutnya dari 18 sampel yang ada, 6 sampel pertama tersebut ditambahkan ragi saccharomyces cereviseae sebanyak 2 gram, kemudian 6 sampel kedua ditambahakan ragi roti sebanyak 4 gram dan 6 sampel ketiga ditambahkan 6 gram ragi roti dan selanjutnya masing-masing sampel ditutup dengan menggunakan aluminium foil kemudian didiamkan selama 24, 48, $72,96,120$, dan 144 jam pada suhu ruang.

\section{Tahap pemisahan}

Larutan hasil fermentasi dimasukkan ke dalam labu alas bulat dan dipasang pada rangkaian alat evaporator. Pada proses ini dilakukan pemanasan pada suhu $78{ }^{\circ} \mathrm{C}$ untuk memisahkan etanol dari campurannya. Larutan hasil evaporasi selanjutnya ditentukan kadarnya dengan menggunakan alkoholmeter.

\section{Hasil dan Pembahasan}

Kadar bioetanol pada berbagai variasi berat ragi dan variasi waktu fermentasi terhadap tepung biji salak

Hasil yang diperoleh pada penentuan kadar bioetanol pada berbagai variasi berat ragi dan variasi waktu fermentasi disajikan pada Tabel.1 dan 2 serta Gambar 1 dan 2.

Tabel 1. Kadar bioetanol pada berbagai variasi berat

\begin{tabular}{|c|c|c|c|c|c|c|c|c|}
\hline \multirow{2}{*}{ No. } & \multirow{2}{*}{$\begin{array}{c}\text { Vol. } \\
\text { Larutan } \\
(\mathrm{mL})\end{array}$} & \multirow{2}{*}{$\begin{array}{c}\text { Berat } \\
\text { Ragi }(g)\end{array}$} & \multicolumn{6}{|c|}{ Kadar Etanol (\%) untuk Waktu (Jam) } \\
\hline & & & 24 & 48 & 72 & 96 & 120 & 144 \\
\hline 1 & 75 & 2 & 6,0 & 10,5 & 7,0 & 5,8 & 5,8 & 5,4 \\
\hline 2 & 75 & 4 & 7,5 & 10,9 & 7,5 & 7,2 & 6,0 & 5,8 \\
\hline 3 & 75 & 6 & 9,0 & 11,2 & 9,4 & 9,4 & 7,5 & 6,9 \\
\hline
\end{tabular}

Tabel 2. Kadar bioetanol pada berbagai variasi waktu fermentasi

\begin{tabular}{cccccc}
\hline \multirow{2}{*}{ No. } & \multirow{2}{*}{$\begin{array}{c}\text { Vol. Larutan } \\
(\mathbf{m L})\end{array}$} & $\begin{array}{c}\text { Waktu } \\
\text { Fermentasi }\end{array}$ & \multicolumn{2}{c}{ Kadar Etanol (\%) untuk Berat Ragi (g) } \\
\cline { 4 - 6 } & & (Jam) & 2 & $\mathbf{4}$ & $\mathbf{6}$ \\
\hline 1 & 75 & 24 & 6,0 & 7,5 & 9,0 \\
2 & 75 & 48 & 10,5 & 10,9 & 11,2 \\
3 & 75 & 72 & 7,0 & 7,5 & 9,4 \\
4 & 75 & 96 & 5,8 & 7,2 & 9,4 \\
5 & 75 & 120 & 5,8 & 6,0 & 7,5 \\
6 & 75 & 144 & 5,4 & 5,8 & 6,9 \\
\hline
\end{tabular}

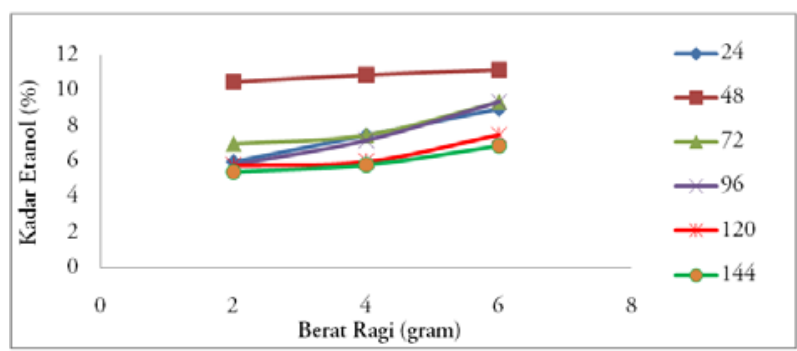

Gambar 1. Kurva pengaruh berat ragi terhadap kadar bioetanol

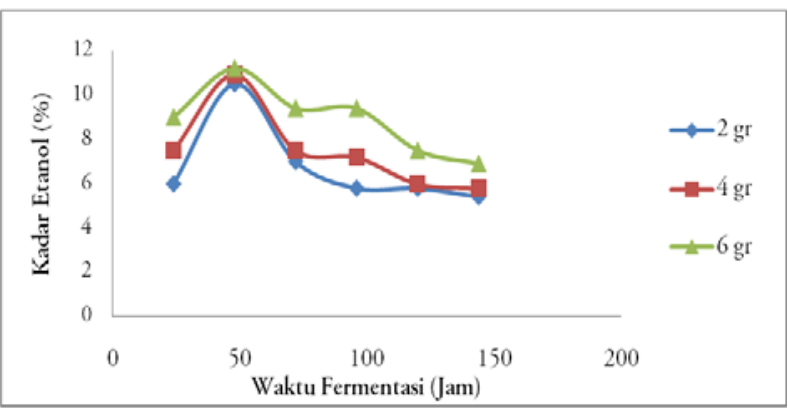

Gambar 2. Kurva pengaruh waktu fermentasi terhadap kadar bioetanol

\section{Pembahasan}

Biji salak merupakan salah satu limbah dari hasil pertanian yang memiliki kandungan kimia utama berupa karbohidrat yaitu sebanyak 38,9\%. 
Kandungan karbohidrat yang cukup tinggi pada biji salak dapat dijadikan sebagai salah satu alternatif untuk bahan baku dalam pembuatan bioetanol (Nico, 2012).

\section{Pengaruh lama waktu fermentasi terhadap kadar bioetanol}

Fementasi adalah proses pemecahan gula sederhana (glukosa atau fruktosa) menjadi etanol dan $\mathrm{CO}_{2}$ dengan melibatkan enzim yang dihasilkan oleh ragi. Fermentasi alkohol dapat dipengaruhi oleh beberapa faktor yaitu media, suhu, jenis mikroba, nutrisi dan $\mathrm{pH}$ (Muksin, 2013). Salah satu faktor yang mempengaruhi proses fermentasi adalah jenis mikroba atau khamir. Jenis khamir yang biasa dipakai pada produk alkohol secara fermentasi adalah saccharomyces cerevisiae. Saccharomyces cerevisiae merupakan khamir yang paling penting pada fermentasi utama dan akhir, karena mampu memproduksi alkohol dengan konsentrasi tinggi dan fermentasi spontan (Rahmawati, 2010).

Proses pembuatan bioetanol diawali dengan mengeringkan sampel biji salak dengan menggunakan oven yang dilanjutkan dengan proses penghalusan hingga diperoleh sampel biji salak halus, yang mana sampel biji salak halus tersebut yang akan dihidrolisis. Tahap ini merupakan tahap yang paling penting dalam proses pembuatan bioetanol, karena proses ini menentukan jumlah glukosa yang dihasilkan untuk kemudian dilakukan fermentasi menjadi bioetanol. Menurut (Assegaf, 2009), prinsip hidrolisis pati adalah pemutusan rantai polimer pati menjadi unitunit dekstrosa atau monosakarida yaitu glukosa $\left(\mathrm{C}_{6} \mathrm{H}_{12} \mathrm{O}_{6}\right)$.

Hidrolisis pati dapat dilakukan dengan bantuan asam atau enzim pada suhu, $\mathrm{pH}$, dan waktu tertentu. Hidrolisis pati secara kimiawi dilakukan dengan menggunakan asam-asam organik sebagai katalisator, yang sering digunakan yaitu $\mathrm{H}_{2} \mathrm{SO}_{4}, \mathrm{HCl}$, dan $\mathrm{HNO}_{3}$ (Mastuti \& Setyawardhani, 2010). Semakin banyak jumlah katalisator yang dipakai makin cepat reaksi hidrolisis terjadi dan dalam waktu tertentu pati yang berubah menjadi glukosa juga meningkat (Sukmawati \& Milati, 2009). Hasil hidrolisis selanjutnya difermentasi dengan berbagai variasi waktu.

Proses fermentasi pada penelitian ini dilakukan dengan variasi waktu fermentasi yaitu 24, 48, 72, 96, 120, dan 144 jam yang dilakukan pada suhu ruang dengan menggunakan ragi saccharomyces cereviseae. Sebelum difermentasi larutan hasil hidrolisis ditambahkan dengan larutan $\mathrm{NaOH}$ hingga $\mathrm{pH}$-nya menjadi 5. Penambahan larutan $\mathrm{NaOH}$ ini bertujuan untuk menentralkan $\mathrm{pH}$ larutan sampel sebelum difermentasi. Jika pada kondisi basa mikroba tersebut tidak dapat tumbuh. Pertumbuhan mikroba saccharomyces cerevisiae dapat berlangsung dengan baik pada kondisi pH 4-5,5 (Akponah \& Akpomie, 2012). Penelitian yang dilakukan oleh (Graves, dkk., 2006) bahwa tidak ada produksi etanol dibwah 4,0 dikarenakan pada $\mathrm{pH}$ ini mikroba tidak dapat tumbuh. Keasaman atau $\mathrm{pH}$ medium merupakan salah satu faktor penting yang mempengaruhi pertumbuhan mikroorganisme dan pembentukan produk dalam proses fermentasi karena setiap mikroorganisme mempunyai kisaran $\mathrm{pH}$ optimal (Idral, dkk., 2012). Sedangkan (Rivera, dkk., 2006) mempertimbangkan bahwa temperatur sebagai variabel untuk mengevaluasi jumlah maksimum yang diharapkan sebagai parameter dari proses fermentasi. Berdasarkan penelitian yang dilakukan, produksi etanol yang maksimum dapta dicapai pada temperatur $28-31{ }^{\circ} \mathrm{C}$. Penelitian Duhan, dkk. (2013) puncak produksi alkohol dicapai pada suhu $35^{\circ} \mathrm{C}$ dan mikroba akan tumbuh optimal pada kisaran temperatur $30-35{ }^{\circ} \mathrm{C}$. Hal ini menunjukan bahwa apabila pada suhu yang terlalu rendah, maka proses fermentasi akan berlangsung secara lambat. Sedangkan pada suhu yang terlalu tinggi menyebabkan mikroba saccharomyces cerevisiae akan mati sehingga proses fermentasi tidak dapat berlangsung. Penelitian ini menggunakan ragi saccharomyces cerevisiae sebagai mikroba karena mikroba saccharomyces cerevisiae dapat menghasilkan alkohol hingga 2\% dalam 72 jam (Oleary, dkk., 2004).

Saccharomyces cerevisiae memiliki kemampuan untuk mengkonversi baik gula dari kelompok monosakarida maupun dari kelompok disakarida. Jika gula yang tersedia dalam substrat merupakan gula disakarida maka enzim invertase akan bekerja menghidrolisis disakarida menjadi monosakarida. Setelah itu, enzim zymase akan mengubah monosakarida tersebut menjadi alkohol dan $\mathrm{CO}_{2}$ (Azizah, dkk., 2012). Fermentasi gula oleh saccharomyces cerevisiae menghasilkan etil alkohol (etanol) dan $\mathrm{CO}_{2}$ dapat dituliskan melalui reaksi sebagai berikut (Retno \& Nuri, 2011):

$$
\mathrm{C}_{6} \mathrm{H}_{12} \mathrm{O}_{6} \stackrel{\text { Saccharomyces cerevisiae }}{\longrightarrow} 2 \mathrm{C}_{2} \mathrm{H}_{5} \mathrm{OH}+2 \mathrm{CO}_{2}
$$

Proses fermentasi dilakukan dengan variasi waktu bertujuan untuk mengetahui dan memperoleh data bagaimana pengaruh waktu fermentasi terhadap kadar etanol yang dihasilkan. Gambar 1 memperlihatkan bagaimana pengaruh waktu fermentasi terhadap kadar bioetanol yang dihasilkan pada berbagai konsentrasi ragi, dimana terlihat bahwa lama waktu fermentasi mempengaruhi kadar bioetanol yang dihasilkan. Pada gambar 1 terlihat bahwa waktu optimum untuk proses fermentasi menggunakan ragi saccharomyces cerevisiae diperoleh pada waktu 48 jam. Namun, pada waktu fermentasi 72 jam hingga 144 jam kadar etanolnya menurun. Ketika waktu optimum fermentasi untuk memperoleh kadar etanol telah dicapai maka akan terjadi penurunan kadar etanol. Penurunan kadar etanol pada waktu fermentasi 72 jam hingga 144 jam disebabkan bakteri saccharomyces cerevisiae mengalami fase pertumbuhan yang lambat dan mengalami fase kematian sehingga aktivitas bakteri untuk mengubah glukosa semakin menurun. Hal ini sesuai dengan pendapat (Hanum, dkk., 2013) bahwa waktu optimal untuk fermentasi alkohol adalah selama 48 jam. Jika melewati waktu optimal akan mengalami penurunan kadar etanol, hal ini disebabkan etnol yang dihasilkan telah diubah 
menjadi asam asetat oleh bakteri tersebut sehingga volume etanol yang dihasilkan mengalami penurunan. Sementara menurut Akin-Osanaiye, dkk. (2005) jika fermentasi dilakukan lebih dari 48 jam, kadar alkoholnya dapat berkurang atau mengalami penurunan. Sedangkan menurut Mandari, dkk. (2014) menyatakan bahwa semakin lama waktu fermentasi maka jumlah mikroba semakin berkurang, dan akan menuju ke fase kematian karena etanol yang dihasilkan semakin banyak dan nutrient yang ada sebagai makanan mikroba semakin menurun.

Seperti mikroorganisme yang lain, pertumbuhan dari saccharomyces cerevisiae dapat digambarkan dengan kurva pertumbuhan yang menunjukkan masing-masing fase pertumbuhan. Ada 4 fase pertumbuhan yang meliputi fase adaptasi, fase tumbuh cepat, fase stasioner, dan fase kematian. Fase adaptasi digambarkan dengan garis kurva dari keadaan nol kemudian sedikit ada kenaikan. Fase ini saccharomyces cerevisiae mengalami masa adaptasi dengan lingkungan dan belum ada pertumbuhan. Fase tumbuh cepat yang digambarkan dengan garis kurva yang mulai menunjukkan adanya peningkatan yang tajam. Pada fase ini saccharomyces cerevisiae mengalami pertumbuhan yang sangat cepat. Fase ini terjadi pemecahan gula secara besar-besaran guna memenuhi kebutuhan pertumbuhan saccharomyces cerevisiae. Hasil pemecahan gula oleh saccharomyces cerevisiae dalam keadaan anaerob menghasilkan alkohol. Kemungkinan dihasilkan alkohol paling tinggi pada fase ini. Fase stasioner digambarkan dengan garis kurva mendatar yang menunjukkan jumlah Saccharomyces cerevisiae yang hidup sebanding dengan jumlah yang mati. Fase kematian digambarkan dengan penurunan garis kurva. Pada fase ini jumlah saccharomyces cerevisiae yang mati jumlahnya lebih banyak sampai akhirnya semua saccharomyces cerevisiae mati (Mandari, dkk., 2014).

Hasil fermentasi tepung biji salak selanjutnya dievaporasi untuk memisahkan etanol dari campurannya pada suhu $78{ }^{\circ} \mathrm{C}$. Pada tahap ini senyawa yang menguap terlebih dahulu adalah etanol karena memiliki titik didih yang rendah yaitu 78,3 ${ }^{\circ} \mathrm{C}$, dibandingkan dengan pelarutnya seperti air yang memiliki titik didih $100{ }^{\circ} \mathrm{C}$ (Ariyani, dkk., 2013). Hasil Evaporasi selanjutnya dilakukan pengukuran kadar etanolnya dengan menggunakan alkoholmeter. Hasil pengukuran kadar etanol dengan waktu optimum selama 48 jam diperoleh sebesar 11,2\%. Berdasarkan hasil yang diperoleh, kandungan etanol terbaik dari biji salak yaitu $11,2 \%$. Mengacu pada SNI 7390: 2012 yang menyatakan bahwa kadar etanol minimum yang digunakan sebagai bahan bakar jenis bioetanol sebesar 94,0-99,5\%. Etanol dari limbah biji salak pada penelitian ini belum dapat di gunakan sebagai bahan baku pembuatan bioetanol. $\mathrm{Hal}$ ini di karenakan pada proses pemisahan perlu dilakukan dengan cara distilasi secara bertingkat, karena untuk mencapai kadar bioetanol di atas 90\% perlu dilakukan distilasi secara terus menerus. Semakin sering dilakukan distilasi bertingkat maka kadar bioetanol yang dihasilkan akan semakin meningkat (Romdloni \& Marsudi, 2014).

\section{Pengaruh berat ragi}

Variasi konsentrasi ragi yang digunakan pada penelitian ini yaitu 2, 4, dan 6 g. Konsentrasi ragi pada proses fermentasi berpengaruh terhadap kadar etanol yang dihasilkan. Pada gambar 2 terlihat berat ragi yang lebih besar yaitu $6 \mathrm{~g}$ dapat menghasilkan kadar etanol yang banyak yaitu sebanyak 11,2\% jika dibandingkan dengan yang $2 \mathrm{~g}$ dan $4 \mathrm{~g}$ hanya menghasilkan kadar etanol sebanyak $10,5 \%$ dan $10,9 \%$. Semakin banyaknya konsentrasi ragi yang diberikan dalam proses fermentasi, maka kadar etanol yang dihasilkan semkain banyak, hal ini disebabkan banyaknya mikroorganisme yang merombak pati menjadi glukosa dan kemudian akan merombak glukosa menjadi alkohol, sehingga menyebabkan kadar etanol yang dihasilkan akan semakin banyak (Karlina, 2008). Hal ini sesuai dengan pendapat (Ocloo \& Ayernor, 2010) yang menyatakan konsentrasi ragi sangat mempengaruhi kadar etanol yang dihasilkan, semakin tinggi kosentrasi ragi yang diberikan, maka semakin banyak alkohol yang dihasilkan. Sedangkan menurut (Moeksin \& Francisca, 2010) menyatakan bahwa semakin besar berat ragi atau konsentrasi ragi yang digunakan maka akan semakin besar pula kadar etanol yang dihasilkan.

\section{Kesimpulan}

Lama waktu fermentasi optimum yang dapat menghasilkan kadar bioetanol tertinggi diperoleh pada waktu 48 jam dengan kadar etanol 11,2\%. Perbandingan berat ragi dengan substrat yang dapat menghasilkan kadar bioetanol tertinggi yaitu 6: 10 .

\section{Ucapan Terima Kasih}

Penulis mengucapkan terima kasih kepada kepala Laboratorium Kimia Lanjut Fakultas Keguruan dan Ilmu Pendidikan Universitas Tadulako dan semua pihak yang telah membantu dalam pelaksanaan penelitian ini.

\section{Referensi}

Akin-Osanaiye, B. C., Nzelibe, H. C., \& Agbaji, A. S. (2005). Production of ethanol from carica papaya (pawpaw) agro waste: effect of saccharification and different treatments on ethanol yield. African Journal of Biotechnology, 4(7), 657-659.

Akponah, E., \& Akpomie, O. O. (2012). Optimization of bio-ethanol production from cassava effluent using saccharomyces cerevisiae. African Journal of Biotechnology, 11(32), 81108116.

Ariyani, E., Kusumo, E., \& Supartono. (2013). Produksi bioetanol dari jerami padi (oryza sativa 1). Jurnal Institut Teknologi Nasional, 2(2), 168 172.

Assegaf, F. (2009). Prospek produksi bioetanol bonggol pisang (musa paradisiacal) menggunakan metode hidrolisis asam dan enzimatis., Karya Tulis Daya Saing Keunggulan dan Penguasaan IPTEKS 
(Ilmu Pengetahuan Teknologi dan Seni). Purwokerto, Universitas Jenderal Soedirman Semarang.

Azizah, N., Al-Baarri, A. N., \& Mulyani, S. (2012). Pengaruh lama fermentasi terhadap kadar alkohol, ph, dan produksi gas pada proses fermentasi bioetanol dari whey dengan substitusi kulit nanas. Jurnal Aplikasi Teknologi Pangan, 1(2), 72-77.

Duhan, J. S., Kumar, A., \& Tanwar, S. K. (2013). Bioethanol production from starchy part of tuberous plant (potato) using saccharomyces cerevisiae mtcc-170. African Journal of Microbiology, 7(46), 5253-5260.

Fauzi, A. F. A. (2011). Pemanfaatan buah pepaya (carica papaya l.) sebagai bahan baku bioetanol dengan proses fermentasi dan distilasi. Laporan Tugas Akhir. Semarang: Fakultas Teknik: Program Studi Diploma III Teknik Kimia Universitas Diponegoro.

Graves, T., Narendranath, N., K, D, \& Power, R. (2006). Effect of $\mathrm{pH}$ and lactic or acetic acid on ethanol productivity by saccharomyces cerevisiae in corn mash. Journal Industrial Microbiology \& Biotechnology, 33(6), 469-474.

Gusmarwani, S. R., Budi, M. S. P., Sediawan, W. B., \& Hidayat, M. (2010). Pengaruh perbandingan berat padatan dan waktu reaksi terhadap gula pereduksi terbentuk pada hidrolisis bonggol pisang. Jurnal Teknik Kimia Indonesia, 9(3), 7782.

Hanum, F., Pohan, N., Rambe, M., Primadony, R., \& lyana, M. (2013). Pengaruh massa ragi dan waktu fermentasi terhadap bioetanol dari biji durian. Jurnal Teknik Kimia USU, 4(2), 1-6.

Idral, D. D., Salim, M., \& Mardiah, E. (2012). Pembuatan bioetanol dari ampas sagu dengan proses hidrolisis asam dan menggunakan saccharomyces cerevisiae. Jurnal Kimia Unand, 1(1), 34-39.

Jhonprimen, H. S., Andreas, T., \& Dahlan, M. H. (2011). Pengaruh massa ragi, jenis ragi dan waktu fermentasi pada bioetanol dari biji durian. Jurnal Teknik Kimia USU, 2(18), 43-51.

Karlina, S. (2008). Pengaruh persentase ragi tape dan lama fermentasi terhadap mutu tape ubi jalar. Teknologi Pertanian Fakultas Pertanian USU. Medan.

Mandari, S., Yenie, E., \& Muria, S. R. (2014). Pembuatan bioetanol dari kulit nanas (ananas comosus l.) menggunakan enzim selulase dan yeast saccharomyces cerevisiae dengan proses simultaneous sacharificatian and fermentation (SSF). Jurnal Online Mahasiswa (JOM) Bidang Teknik dan Sains, 1(1), 1-6.

Mastuti, E., \& Setyawardhani, A. D. (2010). Pengaruh variasi temperatur dan konsentrasi katalis pada kinetika reaksi hidrolisis tepung kulit ketela pohon. Ekuilibrium, 9(1), 23-27.

Moeksin, R., \& Francisca, S. (2010). Pembuatan etanol dari bengkuang dengan variasi berat ragi, waktu, dan jenis ragi. Jurnal Teknik Kimia USU, 2(17), 25-30.

Muksin, F. (2013). Optimasi variasi konsentrasi ragi dan waktu fermentasi dan waktu fermentasi pada pembuatan alkohol pada buah mengkudu. Skripsi Sarjana pada Jurusan Pendidikan Kimia, Universitas Negeri Gorontalo. tidak diterbitkan

Nico, A. (2012). Kandungan gizi biji salak (salacca edulis) ditelaah dari berbagai metode pelunakan biji. Makalah pada Konvensi UKSW. Salatiga.

Ocloo, F. C. K., \& Ayernor, G. S. (2010). Production of alcohol from cassava flour hydrolysate. Journal of brewing and distilling, 1(2), 15-21.

Oleary, V. S., Green, R., Sullivan, B. C., \& Holsinger, V. H. (2004). Alcohol production by selected yeast strains in lactase hydrolyzed acid whey. Journal Biotechnology and Bioengineering, 19(7), 1019-1035.

Osvaldo, Z. S., Panca, P. S., \& Faisal, M. (2012). Pengaruh konsentrasi asam dan waktu pada proses hidrolisis dan fermentasi pembuatan bioetanol dari alang-alang. Jurnal Teknik Kimia USU, 2(18), 52-62.

Rahmawati, A. (2010). Pemanfaatan limbah kulit ubi kayu (manihot utilissima pohl.) dan kulit nanas (ananas comosus l.) pada produksi bioetanol menggunakan aspergillus niger. Skripsi. Surakarta: Jurusan Biologi, Fakultas Matematika dan Ilmu Pengetahuan Alam Universitas Sebelas Maret, tidak diterbitkan.

Retno, T. D., \& Nuri, W. (2011). Pembuatan bioetanol dari kulit pisang. Prosiding Seminar Nasional Teknik Kimia Kejuangan. FTI UPN Vetran Yogyakarta.

Rivera, E., Costa, A., Atala, D., Maugeri, F., Maciel, M., \& Fohlin, R. M. (2006). Evaluation of optimisation techniques for parameter estimation: Application to ethanol fermentation considering the effect of temperature. Journal Process Biochemistry, 41, 1682-1687.

Romdloni, M. A., \& Marsudi. (2014). Pembuatan bioetanol dari sentehijau (alocasia macrorrizha) sebagai bahan bakar alternatif. Journal Teknik Mesin, 3(2), 11-19.

Setyaningsih, D. S. (2012). Optimalisasi penggunaan ragi (saccharomyces cerevisiae) dalam pembuatan bioetanol dari kentang busuk dengan metode hidrolisis enzim. Skripsi Sarjana pada Fakultas Tarbiyah dan Keguruan, Universitas Islam Negeri Sultan Syarif Kasim Riau Pekanbaru. tidak diterbitkan.

Sukmawati, R. F., \& Milati, S. (2009). Pembuatan bioetanol dari kulit singkong. Program Studi Diploma III Teknik Kimia, Fakultas Teknik. Universitas Sebelas Maret Surakarta.

Yusak, Y. (2003). Pengaruh variasi volume $\mathrm{HCl} \mathrm{0,5}$ $\mathrm{N}$ dan waktu hidrolisis terhadap mutu sirup pada pembuatan sirup glukosa dari pati ubi jalar (ipomea batatas l. sin batata edulis choisy). Jurnal Sains Kimia FMIPA-USU Medan, 7(2), 69-73. 

J. Akademika Kim. 6(3): 191-195, August 2017

ISSN 2302-6030 (p), 2477-5185 (e) 